\title{
An outlook on the Sub-Saharan Africa carbon balance
}

\author{
A. Bombelli ${ }^{1}$, M. Henry ${ }^{1,2,3}$, S. Castaldi ${ }^{4}$, S. Adu-Bredu ${ }^{5}$, A. Arneth ${ }^{6}$, A. de Grandcourt ${ }^{7,8}$, E. Grieco ${ }^{1}$, W. L. Kutsch ${ }^{9}$, \\ V. Lehsten ${ }^{6}$, A. Rasile $^{4}$, M. Reichstein ${ }^{9}$, K. Tansey ${ }^{10}$, U. Weber ${ }^{9}$, and R. Valentini ${ }^{1,11}$ \\ ${ }^{1}$ Department of Forest Environment and Resources (DISAFRI), Univ. of Tuscia, via S. Camillo de Lellis, 01100 Viterbo, Italy \\ ${ }^{2}$ Institut de Recherche pour le Développement, IRD, UR SeqBio, SupAgro, Bat. 12, 2 place Viala, \\ 34060 Montpellier Cedex 1, France \\ ${ }^{3}$ AgroParisTech-ENGREF, GEEFT, 648 rue Jean-François Breton, BP 7355 - 34086 Montpellier Cedex 4, France \\ ${ }^{4}$ Dipartimento di Scienze Ambientali, Seconda Università di Napoli, via Vivaldi 43, 81100 Caserta, Italy \\ ${ }^{5}$ Forestry Research Institute of Ghana (FORIG), P.O. Box 63 KNUST, Kumasi, Ghana \\ ${ }^{6}$ Department of Physical Geography and Ecosystems Analysis (INES), Centre for GeoBiosphere Science, Lund University, \\ Sölvegatan 12, 223 62, Lund, Sweden \\ ${ }^{7}$ Centre de coopération Internationale en Recherche Agronomique pour le Développement (CIRAD), Persyst, UPR80, TA \\ B-80/D, 34398 Montpellier Cedex 5, France \\ ${ }^{8}$ Unité de recherche sur la productivité des plantations industrielles (UR2PI), BP 1291, Pointe Noire, Congo \\ ${ }^{9}$ Max-Planck Institute for Biogeochemistry, Hans-Knöll Strasse 10, 07745 JENA, Germany \\ ${ }^{10}$ Department of Geography, University of Leicester, Leicester, LE1 7RH, UK \\ ${ }^{11}$ Euro-Mediterranean Centre for Climate Change (CMCC), via Augusto Imperatore 16, 73100 Lecce, Italy
}

Received: 15 September 2008 - Published in Biogeosciences Discuss.: 20 February 2009

Revised: 14 September 2009 - Accepted: 23 September 2009 - Published: 15 October 2009

\begin{abstract}
This study gives an outlook on the carbon balance of Sub-Saharan Africa (SSA) by presenting a summary of currently available results from the project CarboAfrica (namely net ecosystem productivity and emissions from fires, deforestation and forest degradation, by field and model estimates) supplemented by bibliographic data and compared with a new synthesis of the data from national communications to UNFCCC. According to these preliminary estimates the biogenic carbon balance of SSA varies from $0.16 \mathrm{Pg} \mathrm{C}$ $\mathrm{y}^{-1}$ to a much higher sink of $1.00 \mathrm{Pg} \mathrm{C}^{-1}$ (depending on the source data). Models estimates would give an unrealistic sink of $3.23 \mathrm{Pg} \mathrm{C} \mathrm{y}^{-1}$, confirming their current inadequacy when applied to Africa. The carbon uptake by forests and savannas (0.34 and $1.89 \mathrm{Pg} \mathrm{C} \mathrm{y}^{-1}$, respectively,) are the main contributors to the resulting sink. Fires $\left(0.72 \mathrm{Pg} \mathrm{C}^{-1}\right)$ and deforestation $\left(0.25 \mathrm{Pg} \mathrm{C}^{-1}\right)$ are the main contributors to the SSA carbon emissions, while the agricultural sector and forest degradation contributes only with 0.12 and $0.08 \mathrm{Pg} \mathrm{C} \mathrm{y}^{-1}$, respectively. Savannas play a major role in shaping the SSA carbon balance, due to their large extension, their fire regime, and their strong interannual NEP variability, but they are also a major uncertainty in the overall budget. Even if fossil fuel
\end{abstract}

Correspondence to: A. Bombelli (bombelli@unitus.it) emissions from SSA are relative low, they can be crucial in defining the sign of the overall SSA carbon balance by reducing the natural sink potential, especially in the future. This paper shows that Africa plays a key role in the global carbon cycle system and probably could have a potential for carbon sequestration higher than expected, even if still highly uncertain. Further investigations are needed, particularly to better address the role of savannas and tropical forests and to improve biogeochemical models. The CarboAfrica network of carbon measurements could provide future unique data sets for better estimating the African carbon balance.

\section{Introduction}

The climate system is strongly linked to the global carbon cycle: $\mathrm{CO}_{2}$ is, by far, the largest contributor to the anthropogenically enhanced greenhouse effect (IPCC, 2007a), while at the same time, a large proportion of the emitted $\mathrm{CO}_{2}$ is absorbed by ocean and terrestrial ecosystems. Improving our knowledge of terrestrial sources and sinks of $\mathrm{CO}_{2}$ and other greenhouse gases (GHGs), and their spatial and temporal variability is a key action to: 1) better understand and predict the global change, and 2) enhance human capacity to undertake mitigation and adaptation actions.

Published by Copernicus Publications on behalf of the European Geosciences Union. 
The role of the African continent in the global carbon cycle, and therefore in climate change, is increasingly recognised (Houghton and Hackler, 2006; Williams et al., 2007). Even if Africa contributes only less than $4 \%$ to the global anthropogenic fossil fuel emissions (Canadell et al., 2009), it is a major source of interannual variability in global atmospheric $\mathrm{CO}_{2}$ (Williams et al., 2007): $20 \%$ of both global net primary production (NPP) and global land use emissions (mainly from forest degradation and deforestation), and around $40 \%$ of fire emissions have been attributed to the African continent, significantly affecting the atmospheric chemistry (Andreae, 1991; Houghton, 2003; Kituyi et al., 2005; van der Werf et al., 2006).

In Sub-Saharan Africa (SSA) the role of land use change in controlling $\mathrm{CO}_{2}$ emissions and annual $\mathrm{C}$ budgets at regional and global scale may be more critical than in any other regions (Houghton and Hackler, 2006): with low fossil fuel emissions, Africa's current continental scale carbon fluxes are dominated by uptake and release from terrestrial ecosystems (which in turn are strongly linked to climate fluctuations) as well as forest degradation and deforestation (Williams et al., 2007). African forests contain large carbon stocks in biomass, up to $255 \mathrm{Mg} \mathrm{C} \mathrm{ha}^{-1}$ in tropical rainforests (Palm et al., 2000), that appear to be particularly vulnerable, mainly due to the impact of climate change, land use change, population increase and political instability. Africa's land use pressures will undoubtedly increase in the next years and the forecasted increase in drought and temperature (IPCC, 2007a) can lead to a significant decrease in ecosystem carbon stocks in tropical forests and savanna, at least without human countermeasures (Tan et al., 2009).

Despite the increasingly acknowledged importance of Africa in the global carbon cycle and its high vulnerability to climate change due to both ecological and socio-economic factors, there is still a lack of studies on the carbon cycle in representative African ecosystems, in particular tropical forests. Up to now it is not clear whether Africa is a net carbon absorber or emitter, however Williams et al. (2007), in their comprehensive recent review on the African carbon cycle, showed that Africa's decadal scale mean carbon balance appears to be neutral, whereas latest results by Ciais et al. (2009) showed that in the last decade Africa has probably been acting as a net carbon sink.

Many open questions remain also on soil $\mathrm{GHG}\left(\mathrm{CH}_{4}, \mathrm{CO}_{2}\right.$ and $\mathrm{N}_{2} \mathrm{O}$ ) fluxes, especially in tropical seasonally-dry areas.

This lack of data on African carbon budget makes the numerical models of the carbon cycle highly uncertain when applied to Africa; model simulations can provide just an approximate profile of Africa since these models are usually developed and validated for different latitudes (Chevallier et al., 2009; Ciais et al., 2009; Weber et al., 2009). Therefore there is a strong need for a denser and more representative network of carbon observation stations over Africa in order to improve the regional carbon estimates using biogeochem- ical models (Williams et al., 2007; Ciais et al., 2009; Weber et al., 2009).

In addition, a deeper knowledge of the African potential to mitigate climate change through carbon sequestration and reduction of emissions is highly required by the current international climate policy. It is thus important to quantify both carbon stocks and fluxes of African forests and other ecosystems, especially in the context of the UNFCCC (United Nations Framework Convention on Climate Change) mechanisms, such as the Clean Development Mechanisms (CDM) of the Kyoto protocol, and the Reducing Emissions from avoided Deforestation and forest Degradation (REDD).

As a consequences of the above arguments the project CarboAfrica, funded by the European Commission, was launched in 2006 in order to: 1) support a network of continued and enhanced continent-wide observations of SubSaharan Africa's carbon stocks, fluxes, atmospheric concentrations and ecological processes; 2) improve biogeochemical models representing the main African ecosystem types; 3 ) better understand the role of fire emissions of SSA in the global carbon cycle; and 4) assess the potential of SSA for carbon sequestration and emission reduction.

In this paper we present an outlook on the carbon balance of SSA by using first results from the project CarboAfrica (namely net ecosystem productivity and emissions from fires, deforestation and forest degradation, by field and model estimates) supplemented by bibliographic data and compared with a new synthesis of the data from national communications to UNFCCC, in order to contribute towards: 1) a better quantification of the terrestrial carbon budget of SSA, and 2) the improvement of our understanding of the role of SSA in the global carbon cycle.

\section{Methodology}

Results of this paper have been obtained using both published and unpublished data of the CarboAfrica project, supplemented by bibliographic data and compared with a new synthesis of the data from national communications to UNFCCC. The study area is Sub-Saharan Africa (hereinafter called SSA). In particular, research activities are being conducted in the following SSA countries: Benin, Botswana, Burkina Faso, Ghana, Ivory Coast, Mali, Niger, Congo, South Africa, Sudan and Zambia. Other SSA countries may be considered before the end of the project.

\subsection{The CarboAfrica methodology}

The CarboAfrica methodology is based on an integrated multiscale and multitemporal approach. The work is divided in 6 work packages, dealing with: long term observation systems and data integration and consolidation; process understanding of carbon fluxes of SSA ecosystems; model-data integration for up-scaling to region and 


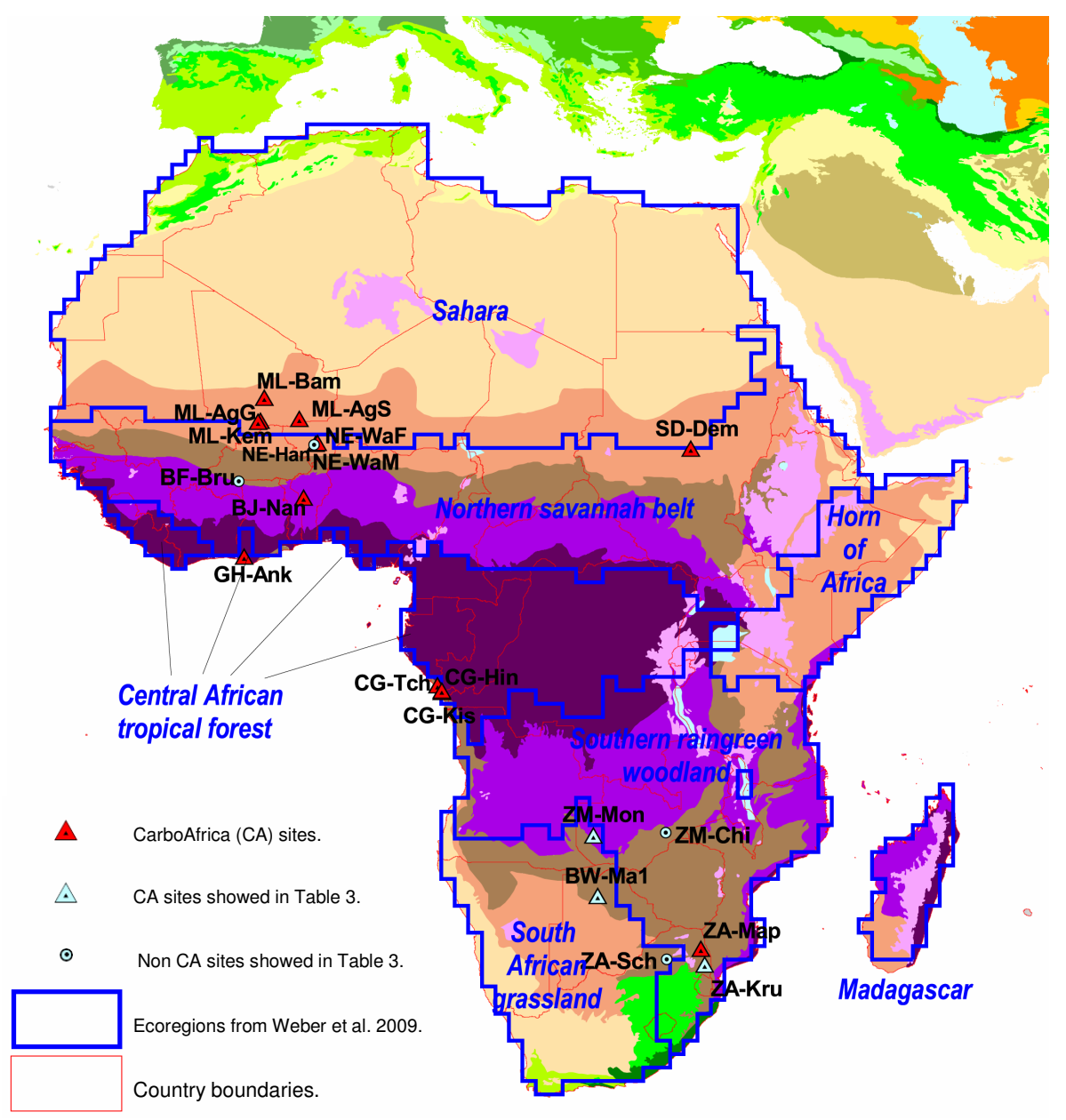

Fig. 1. Global Ecological Zone map of Africa (FAO, FRA, 2001. http://www.fao.org:80/geonetwork?uuid= baa463d0-88fd-11da-a88f-000d939bc5d8) showing the location of the sixteen eddy covariance sites that are run by or contribute data to the CarboAfrica project. Overlapped are the borders of the major eco-regions of Sub-Saharan Africa as defined by Weber et al. (2009) on the basis of the broad distribution of ecosystem types and used to extend models and field data. The legend of the Ecological Zones classes is shown in Fig. A1 of Appendix A.

continent; fire-climate-carbon cycle interactions on regional and continental scale; evaluation of a sustainable sequestration potential in relation with CDM; communications and capacity building. More details on the project methodology is available at: www.carboafrica.net.

\subsubsection{Carbon stock and fluxes}

The observational backbone of the project is constituted by the experimental eddy covariance flux network (Fig. 1) for gas exchange measurements (carbon, water and energy fluxes) between ecosystems and the atmosphere at landscape scale $^{1}$ (see Archibald et al., 2009; Merbold et al., 2009, for details on the eddy covariance methodology) for details on the eddy covariance methodology). This long-term observa-

\footnotetext{
${ }^{1}$ In this paper positive values of carbon fluxes represent carbon sink and negative values represent carbon source.
}

tion system integrates data from at least eighteen intensive study sites, established within CarboAfrica as well as via a number of other research projects (sixteen eddy covariance sites, of which one mobile station in three different sites and two atmospheric stations), covering a range of representative land cover, from tropical forest to desert, going through different woodland types, different savanna types, grasslands, Eucalyptus plantations, and different agricultural crops. This network includes the first flux station in an African tropical forest, which is providing new information on the Africa's role in the global carbon cycle. Biomass samples are being taken to provide additional data for carbon estimates validation. Above ground biomass data used to produce the figures of this paper have been derived from the last IPCC report (2007a). We have used the data from Henry and collaborators (unpublished) to make an estimation of Soil Organic Carbon (SOC) for the different classes of FAO forest ecological classification (FAO, 2006). 


\subsubsection{Ecosystem processes}

Intensive field campaigns at the flux sites of Fig. 1 were conducted to measures ecosystem processes in soil and vegetation, including soil and plant water relations and gas exchange $\left(\mathrm{CO}_{2}\right.$, but also $\mathrm{CH}_{4}$ and $\left.\mathrm{N}_{2} \mathrm{O}\right)$, plant phenology and plant ecophysiology (see also Kutsch et al., 2008, for more details).

\subsubsection{Modelling}

In situ and remote sensing data were integrated for the model parameterisation and evaluation. Different models, from data oriented to process oriented, were used to provide a multiple constraint approach to the continental carbon cycle integration. This allows covering the model domain in terms of variable temporal scales, spatial scales and processes addressed. Data presented here were extracted from a simulation experiment on the interannual variability of Africa's ecosystem productivity (Weber et al., 2009). It is noteworthy that the models were developed mostly for other continents and are not validated against site data for the annual carbon balance of SSA. See also Chevallier et al. (2009), Ciais et al. (2009), Seaquist et al. (2009), and Sjöström et al. (2009), for more details on the models used by CarboAfrica.

\subsubsection{Fires}

The CarboAfrica fire approach considers both burned area extent and fire intensity and emission. Remote sensing based carbon emission estimates from fires were derived by combining the mapping of burned area and the fire radiative energy (FRE) technology (see also Lehsten et al., 2009; Roberts et al., 2009). The interactions of ecosystem productivity with fire patterns was studied using a combination of prescribed burned area (based on the L3JRC analysis) and the dynamic vegetation model (DVM) LPJ-GUESS with the fire model SPITFIRE included (Smith et al., 2001; Thonicke et al., 2009). Using a DVM provides a tool to disentangle the interactions of precipitation, NPP and litter production as the main drivers of fires, and to investigate whether global patterns emerge that are generally representative for savanna ecosystems.

\subsubsection{GHGs emissions}

GHGs emission data were extracted from the African countries national communication to the United Nations Framework Convention on Climate Change (UNFCCC). The following classes were considered: anthropogenic emissions (regrouping emissions from the energy, industry and waste sectors); agriculture emissions; Land Use Change and Forestry (LUCF) emissions; and removals (i.e. the carbon capture from the atmosphere and storage in terrestrial ecosystems). The base year adopted for most of the countries was 1994 except for Sierra Leone and Egypt (1990), Gambia and
Chad (1993), Togo, Mali, Mauritania and Sudan (1995) and Burundi (1998). All data were converted to $\mathrm{CO}_{2}$ equivalent on the basis of the Global Warming Potential as reported in IPCC (2007b). We have not considered some data because they were not reliable. South Africa's emissions by LUCF sector is zero because of intensive afforestation activities, expansion of plantations and conservation policies (as reported in its National Communication).

National data were regrouped in three different African regions: Northern Africa, Sub-Saharan Africa and South Africa. Northern Africa was defined as composed of: Algeria, Egypt, Libya, Morocco, Tunisia and Western Sahara. The remaining countries were considered to belong to SSA, excluding South Africa, which has been considered individually. Per-capita data have been derived by dividing the emission values by the population (UN, 2006).

\section{Results and discussion}

\subsection{The Sub-Saharan carbon balance: an overview of current estimates}

According to the National Communications to UNFCCC, there is a great disproportion among emissions from different African regions (Table 1). South Africa is the main carbon emitter, producing about $14 \%$ of the global African emissions $\left(403 \mathrm{Tg}\right.$ eq $\mathrm{CO}_{2}$ ). This result is much more evident if we compare per-capita anthropogenic emissions: South

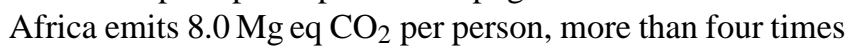
of both the northern Africa and the rest of SSA.

Considering the low fossil fuel emissions, SSA carbon balance is dominated by two large fluxes: emissions from land use change and uptake by terrestrial ecosystems. Excluding South Africa, emissions from LUCF and agriculture sector in SSA are $1845 \mathrm{Tg}$ eq $\mathrm{CO}_{2}$ and removals $-2461 \mathrm{Tg}$ eq $\mathrm{CO}_{2}$. Combining all the emissions (including fossil fuel) and removals, SSA (excluding South Africa) is currently a net sink of $312 \mathrm{Tg}$ eq $\mathrm{CO}_{2}$. However, considering the sources from Northern and South Africa, by the current available National Communications the whole African continent appears to be a small source of $359 \mathrm{Tg}$ eq $\mathrm{CO}_{2}$.

However the SSA carbon balance, due to relatively small net difference between the two large fluxes of emissions and removals, is subjected to large interannual variability and to high uncertainties in the data used to report to UNFCCC national inventories.

The overall annual carbon balance of SSA region (CB) can be summarized into its main components as:

$\mathrm{CB}=\mathrm{NEP}-\mathrm{EFS}-\mathrm{D}-\mathrm{FD}-\mathrm{A}-\mathrm{FF}-\mathrm{LT}+\mathrm{R}$

Where NEP is net ecosystem productivity of terrestrial ecosystems, EFS emissions from savanna fires, D emissions from deforestation (e.g. change of land use), FD emissions from forest degradation (e.g. logging), A emissions from 
Table 1. Total annual GHG emission estimates (above) and per-capita values (below) for three different African regions: Northern Africa (NA), Sub-Saharan Africa - excluding South Africa (SSA ${ }^{\mathrm{a}}$ ) and South Africa (SA). The following sectors were considered: anthropogenic emissions (regrouping emissions from the energy, industry and waste sectors); agriculture emissions; Land Use Change and Forestry (LUCF) emissions; and removals. Data were processed from the African countries national communication to the United Nations Framework Convention on Climate Change (UNFCCC). All data were converted to $\mathrm{CO}_{2}$ equivalent on the base of Global Warming Potential reported in IPCC (2007b). South Africa's emissions by LUCF sector is zero because of intensive afforestation activities, expansion of plantations and conservation policies. See Sect. 2.1.5 for more details.

\begin{tabular}{lcccccc}
\hline Region & $\begin{array}{c}\text { Emissions sources } \\
\text { Anthropogenic } \\
{\left[\mathrm{Tg} \mathrm{eq} \mathrm{CO}_{2}\right]}\end{array}$ & $\begin{array}{c}\text { Agriculture } \\
{\left[\mathrm{Tg} \mathrm{eq} \mathrm{CO}_{2}\right]}\end{array}$ & $\begin{array}{c}\mathrm{LUCF} \\
{\left[\mathrm{Tg} \mathrm{eq} \mathrm{CO}_{2}\right]}\end{array}$ & $\begin{array}{c}\text { Total emissions } \\
{\left[\mathrm{Tg} \mathrm{eq} \mathrm{CO}_{2}\right]}\end{array}$ & $\begin{array}{c}\text { Removals } \\
{\left[\mathrm{Tg} \mathrm{eq} \mathrm{CO}_{2}\right]}\end{array}$ & $\begin{array}{c}\text { Net emission } \\
{\left[\mathrm{Tg} \mathrm{eq} \mathrm{CO}_{2}\right]}\end{array}$ \\
\hline $\mathrm{NA}$ & 235 & 51 & 25 & 312 & 25 & 287 \\
$\mathrm{SSA}^{\mathrm{a}}$ & 338 & 375 & 1470 & 2145 & 2461 & -312 \\
$\mathrm{SA}$ & 364 & 39 & 0 & 403 & 19 & 384 \\
Total Africa & 938 & 465 & 1495 & 2860 & 2505 & 359 \\
\hline \multirow{2}{*}{ Per-capita } & Anthropogenic & Agriculture & $\mathrm{LUCF}$ & Total emissions & Removals & Net emission \\
\hline NA & 1.7 & 0.4 & 0.2 & 2.2 & 0.2 & 2.0 \\
SSA $^{\text {a }}$ & 0.5 & 0.6 & 2.3 & 3.4 & 3.9 & -0.5 \\
SA & 8.0 & 0.9 & 0.0 & 8.9 & 0.4 & 8.5 \\
Total Africa & 1.1 & 0.6 & 1.8 & 3.5 & 3.1 & 0.4 \\
\hline
\end{tabular}

$\mathrm{a}=$ excluding South Africa

agriculture, FF emissions from fossil fuel, LT lateral transport of carbon from the region (rivers, trade, food consumption etc.) and $\mathrm{R}$ precipitation inputs. We can disregard in a first assumption both LT and P (that partially counterbalance each other), assume for agriculture the emission statistics of UNFCCC, and try to address more in details the other components.

\subsection{C stocks and NEP of SSA terrestrial ecosystems}

A comprehensive analysis of the role of terrestrial ecosystem carbon contribution to the SSA carbon balance should be based on inventories of carbon pools and their changes in time, direct flux measurements (as from the CarboAfrica network, see Kutsch et al., 2008; Archibald et al., 2009; Merbold et al., 2009) and process-based biogeochemical models that derive NEP from estimates of GPP and ecosystem respiration (Ciais et al., 2009; Friedlingstein et al., 2009; Weber et al., 2009). Since CarboAfrica network is currently under operation and long term data sets are not yet available consistently through all the sites, we present only few direct flux results and concentrate our analysis on existing inventory data and models derived outputs.

In broadest terms, the two dominant vegetation types in SSA are forests (ranging from tropical to mountain regions) and savannas (ranging from grasslands to woodlands).

Most of the forest biomass in Africa is localized in the Sub-Saharan region and more precisely in the Central African belt. Estimates of above-ground dry biomass in

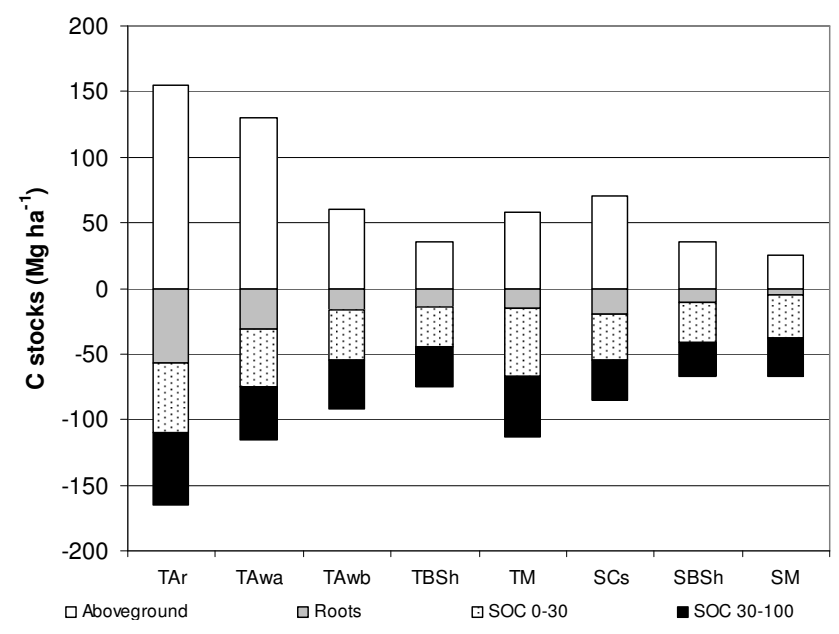

Fig. 2. Distribution of $\mathrm{C}$ stocks among different African forest ecosystems. Tar $=$ Tropical rain forests, TAwa $=$ Tropical moist deciduous forests, TAwb = Tropical dry forests, $\mathrm{TBSh}=$ Tropical shrublands, $\mathrm{TM}=$ Tropical mountains, $\mathrm{SCs}=$ Subtropical dry forests, $\mathrm{SBSh}=$ Subtropical steppes, $\mathrm{SM}=$ Subtropical mountain systems. Aboveground biomass and root $\mathrm{C}$ were obtained from IPCC (2007) and SOC was obtained from Henry (unpublished).

African tropical forests vary among authors, ranging from 30 to $255 \mathrm{Mg} \mathrm{C} \mathrm{ha}^{-1}$ (Brown, 1997; Palm et al., 2000; Houghton and Hackler, 2006; IPCC, 2007a). As reported in Fig. 2, mean aboveground $\mathrm{C}$ accumulated in humid tropical forests is $155 \mathrm{Mg} \mathrm{C} \mathrm{ha}^{-1}$ (IPCC, 2007a). Above ground 
Table 2. Gross Primary Productivity (GPP), Net Primary Productivity (NPP) and Net Ecosystem Productivity (NEP) in different African ecoregions (as defined by Weber et al., 2009). Data are presented per unit of surface (a) and extended to different African regions (b). Data were extrapolated from Weber et al. (2009) by averaging the estimates from the four different model used.

\begin{tabular}{lccc}
\hline (a) & $\begin{array}{c}\mathrm{GPP} \\
\mathrm{g} \mathrm{C} \mathrm{m}^{-2} \mathrm{y}^{-1}\end{array}$ & $\begin{array}{c}\mathrm{NPP} \\
\mathrm{g} \mathrm{C} \mathrm{m}^{-2} \mathrm{y}^{-1}\end{array}$ & $\begin{array}{c}\mathrm{NEP} \\
\mathrm{g} \mathrm{C} \mathrm{m}^{-2} \mathrm{y}^{-1}\end{array}$ \\
\hline Northern Savanna Belt & $1341 \pm 474$ & $649 \pm 184$ & $248 \pm 50$ \\
Central Africa Tropical Forest & $2558 \pm 733$ & $1151 \pm 431$ & $345 \pm 241$ \\
Horn of Africa & $919 \pm 386$ & $428 \pm 160$ & $155 \pm 29$ \\
Suthern Raingreen woodland & $1572 \pm 576$ & $702 \pm 213$ & $262 \pm 64$ \\
South African Grassland & $831 \pm 348$ & $367 \pm 111$ & $139 \pm 32$ \\
\hline & & & \\
\hline (b) & $\mathrm{GPP}$ & $\mathrm{NPP}$ & $\mathrm{NEP}$ \\
& $\mathrm{Pg} \mathrm{C} \mathrm{y}$ & $\mathrm{Pg} \mathrm{C} \mathrm{y}$ & $\mathrm{Pg} \mathrm{C} \mathrm{y}$ \\
\hline Northern Savanna Belt & $8.83 \pm 3.12$ & $4.27 \pm 1.21$ & $1.63 \pm 0.33$ \\
Central Africa Tropical Forest & $7.31 \pm 2.09$ & $3.29 \pm 1.23$ & $0.98 \pm 0.69$ \\
Horn of Africa & $1.52 \pm 0.64$ & $0.71 \pm 0.26$ & $0.26 \pm 0.05$ \\
Suthern Raingreen woodland & $7.40 \pm 2.71$ & $3.31 \pm 1.00$ & $1.23 \pm 0.30$ \\
South African Grassland & $2.12 \pm 0.89$ & $0.93 \pm 0.28$ & $0.35 \pm 0.08$ \\
Sub-Saharan Savannas & $19.87 \pm 3.69$ & $9.22 \pm 1.76$ & $3.48 \pm 0.67$ \\
Sub-Saharan Africa & $27.17 \pm 3.36$ & $12.51 \pm 1.59$ & $4.46 \pm 0.58$ \\
\hline
\end{tabular}

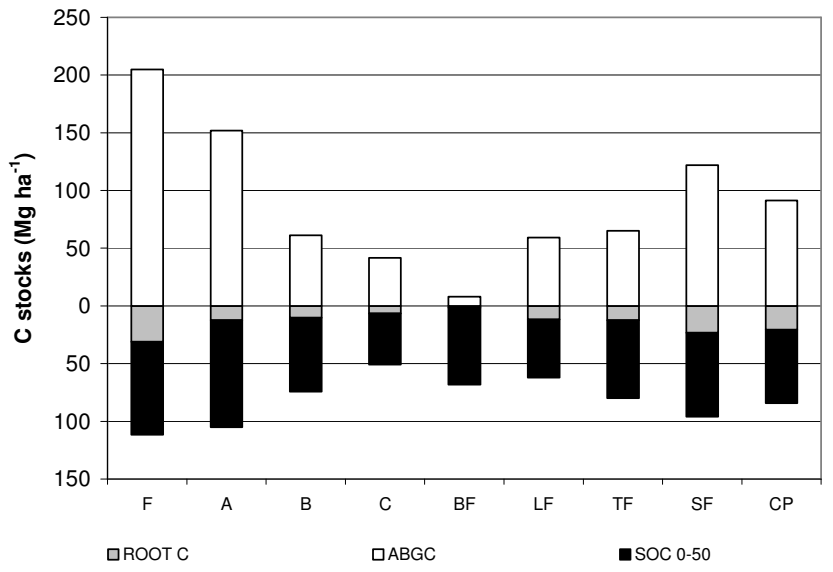

Fig. 3. Carbon stocks in humid tropical ecosystems of Cameroon under different management. $\mathrm{F}=$ Forest, $\mathrm{A}=$ Cucumber based farm, $\mathrm{B}=$ Banana farm, $\mathrm{C}=$ Cropland $* \mathrm{BF}=$ Bush fallow; $\mathrm{LF}=$ Long fallow, $\mathrm{TF}=$ Tree fallow, $\mathrm{SF}=$ Secondary forest, $\mathrm{CP}=$ Cocoa plantation. Data were obtained from Kotto-Same et al. (1997) and Kanmegne (2004). $*$ = crop mixtures (maize, groundnuts, cassava, banana).

carbon stocks decrease from tropical forest with a minimum in the mountain forests, due to limitations of climate and soil on forest productivity (Fig. 2). Tropical rain forests show the highest belowground $\mathrm{C}$, both for the $\operatorname{root}\left(57 \mathrm{Mg} \mathrm{C} \mathrm{ha}^{-1}\right)$ and the soil components (53 and $55 \mathrm{Mg} \mathrm{C}^{-1}$ for $0-30$ and $0-100 \mathrm{~cm}$ ) while minimum values are shown by mountain forests. Both above ground and below ground $\mathrm{C}$ stocks vary between different forest management types (Fig. 3). The conversion of forest to other land use types involves significant changes in $\mathrm{C}$ stocks, particularly SOC. While the maximum SOC was observed in logged forest $\left(77 \mathrm{Mg} \mathrm{C} \mathrm{ha}^{-1}\right)$ the minimum SOC was observed in recent bush fallow 66 (Mg C $\left.\mathrm{ha}^{-1}\right)$. Similar trend was observed by Houghton (1999) who estimated SOC of about 100 and $50 \mathrm{Mg} \mathrm{ha}^{-1}$ in undisturbed closed and open forests, respectively.

From FAO statistics (FAO, 2006) and IPCC data (IPCC, 2007a) it is possible to derive an overall assessment of the $C$ stocks in SSA forests. Above ground carbon stock for SSA forests is equal to $48 \mathrm{Pg} \mathrm{C}$. Integrating our unpublished data in combination with FAO and IPCC data is possible to estimate the contribution of belowground $\mathrm{C}$ stock, which include roots and soil organic carbon, to be equal to $161 \mathrm{Pg}$ in SSA for $0-100 \mathrm{~cm}$ soil layer. The total $\mathrm{C}$ stocks for SSA can thus be considered to be $209 \mathrm{Pg} \mathrm{C}$, of which about $77 \%$ is coming from belowground carbon.

NEP estimates from forest inventories are difficult to obtain. We can consider the current UNFCCC national communication data as an overall estimate (see Table 1) which gives a total removal (mainly forests) of $1.13 \mathrm{Pg} \mathrm{C}^{-1}$ for SSA. This value is comparable to recent model results from CarboAfrica that provide a new insight in NEP estimation for forests. SSA forest NEP according to several models (Weber et al., 2009) can be estimated as $0.98 \pm 0.69 \mathrm{Pg} \mathrm{C} \mathrm{y}^{-1}$ (see Table 2). This value can be regarded as a first approximation considering Central Africa tropical forest (as defined by Weber et al., 2009) as the main forest region of SSA. 
Table 3. Net Primary Productivity (NPP) and Net Ecosystem Productivity (NEP) in different savannas. When needed original data were converted to $\mathrm{Mg} \mathrm{C}_{\mathrm{Ca}}^{-1} \mathrm{y}^{-1}$. NSB = Northern Savannah Belt, SRW = Southern Raingreen Woodlands, SAG = South African grasslands * = CarboAfrica data.

\begin{tabular}{lccc}
\hline Citation & Region & $\begin{array}{c}\mathrm{NPP} \\
\mathrm{Mg} \mathrm{C} \mathrm{ha}^{-1} \mathrm{y}^{-1}\end{array}$ & $\begin{array}{c}\mathrm{NEP} \\
\mathrm{Mg} \mathrm{C} \mathrm{ha}^{-1} \mathrm{y}^{-1}\end{array}$ \\
\hline Scholes and Walker (1993) & SAG & 3.81 & 1.23 \\
Hanan et al. (1998) & NSB & 3.31 & 0.32 \\
Chidumayo (2002) & SRW & & 0.42 \\
Veenendaal et al. (2004) & SAG & & 0.12 \\
Grace et al. (2006) & Africa & 5.8 & \\
Grace et al. (2006) & Global & 7.2 & 0.14 \\
van der Werf et al. (2006) & Africa & 18.2 & \\
Grace, unpublished in Ciais et al. (2009) & Africa & 5.9 & \\
Brümmer et al. (2008) & NSB & & 4.53 \\
Archibald et al. (2009) & SAG & & -0.25 \\
Lehsten et al. (2009) & Africa & 6.3 & \\
Kutsch and Merbold (unpublished) & SRW & 16.27 & 0.05 \\
& Average & $8.35 \pm 5.65$ & $0.82 \pm 1.56$ \\
\hline
\end{tabular}

Tropical drought-deciduous woodlands, savannas, shrublands, thickets and grasslands form a seamless continuum which can only be divided into distinct structural types by applying arbitrary limits (Scholes and Hall, 1996). In this paper we use the term savanna to indicate the co-occurrence of trees and grasses in different proportion (Sankaran et al., 2004), ranging from grassland to woodland, and defined by Scholes and Hall (1996) as "tropical tree-grass systems". This system covers the majority of the surface of the following African ecoregions, as defined by Weber et al. (2009): Northern Savannah belt, Horn of Africa, Southern raingreen woodlands, and South African grasslands. According to the above definition, Sub-Saharan savannas (including grasslands and open woodlands) cover an area of about 15 million $\mathrm{km}^{2}$ which corresponds to more than $80 \%$ of SSA land area. However this area, and the consequent extrapolations, is overestimated because the above African ecoregions contain also other different ecosystem types.

NPP estimates of savanna ecosystems are available from a number of studies, but only few estimates are available for NEP, and they vary from a source value of $-0.25 \mathrm{Mg} \mathrm{C}$ $\mathrm{ha}^{-1} \mathrm{y}^{-1}$ (Archibald et al., 2009) to a sink value of $4.53 \mathrm{Mg}$ $\mathrm{C} \mathrm{ha}^{-1} \mathrm{y}^{-1}$ (Brümmer et al., 2008) (see Table 3). The CarboAfrica project is trying to fill in this gap and some first results are given in Table 3 (Kutsch et al., 2008; Archibald et al., 2009; Merbold et al., 2009). The field observations deviate substantially from the NEP data extrapolated from the modelling intercomparison across the different African ecoregions of Weber et al. (2009) (Table 2). This shows the uncertainty in modelling as well as field estimates: the current model runs estimate an overall carbon budget of $3.48 \pm 0.67 \mathrm{Pg} \mathrm{C} \mathrm{y}^{-1}$. Field measurements in Table 3 are regrouped in the different African ecoregions of Weber et al. (2009), as shown in Fig. 1. By extending the average NEP value of each ecoregion on its respective land surface and summing the total values of each ecoregion we obtain a smaller sink strength $\left(1.89 \mathrm{Pg} \mathrm{C} \mathrm{y}^{-1}\right)$ than the models ${ }^{2}$. Numerous processes that can impede the carbon sink are not or not adequately included in the modelling (e.g. nutrient limitation, herbivores, indirect effects of fire, etc.). The model estimates consider northern savannas, southern rain-green woodlands and grasslands, as well as horn of Africa all together as the dominant savanna like ecosystems of SSA, but do not consider carbon emissions from fires.

According to the preliminary modelling results, forest ecosystems have much larger productivity per unit of land area (about $13 \mathrm{Mg} \mathrm{ha}^{-1} \mathrm{y}^{-1}$ ) compared to NEP for savannas $\left(2 \mathrm{Mg} \mathrm{ha}^{-1} \mathrm{y}^{-1}\right)$. However the savannas are extending over a much larger area and thus they determine significantly the carbon budget of the region. As we will see below, the annual net carbon balance of SSA is dominated by savannas fires, which reduce considerably their effect as a large sink of carbon.

\subsection{The role of savanna fires (EFS) in the SSA carbon balance}

Africa GHG emissions are highly affected by vegetation fires, contributing substantially to the total carbon emissions over large parts of the continent (Lehsten et al., 2009). Estimates of biomass burned annually in Africa are very different; however they are often around thousands of $\mathrm{Tg}$ of biomass (Andreae, 1993; Hao et al., 1996; Ito and Penner,

\footnotetext{
${ }^{2}$ For the ecoregion Horn of Africa, where no field sites are available, we used the average NEP value of SSA savannas extended on its land surface.
} 
Table 4. Data related to deforestation and forest degradation in the Congo Basin African countries. Source of data is specified in the footnote.

\begin{tabular}{|c|c|c|c|c|c|c|c|}
\hline & Cameroon & Gabon & Congo & DRC & CAR & Equatorial Guinea & Congo Basin \\
\hline \multicolumn{8}{|l|}{ Land surface $(1000 \mathrm{ha})^{\mathrm{a}}$} \\
\hline Land area & 46540 & 25767 & 34150 & 226705 & 62298 & 2805 & 398265 \\
\hline Dense forest area & 21436 & 21190 & 25914 & 124566 & 8227 & 1843 & 203176 \\
\hline Production forests & 10500 & 19000 & 12000 & 87000 & 3300 & 1250 & 133050 \\
\hline Area under forest management process & 4348 & 6368 & 7115 & 9680 & 2994 & 55 & 30560 \\
\hline \multicolumn{8}{|l|}{ Annual forest cover change $(\%)^{b}$} \\
\hline Gross deforestation & -0.28 & -0.16 & -0.12 & -0.33 & -0.15 & -0.35 & -0.27 \\
\hline Net deforestation & -0.19 & -0.12 & -0.03 & -0.26 & -0.07 & 0.41 & -0.19 \\
\hline Net degradation & -0.02 & -0.09 & -0.01 & -0.15 & -0.02 & 0.52 & -0.1 \\
\hline FAO deforestation & -0.9 & 0.05 & -0.1 & -0.4 & -0.1 & -0.6 & -0.36 \\
\hline \multicolumn{8}{|l|}{ Average $\mathrm{C}$ stocks $\left(\mathrm{Mg} \mathrm{C}^{-1}\right)^{\mathrm{c}}$} \\
\hline $\mathrm{SOC}(0-30 \mathrm{~cm})$ & 52 & 51 & 75 & 49 & 41 & 70 & 54 \\
\hline Aboveground $\mathrm{C}$ & 90 & 167 & 231 & 173 & 123 & 70 & 142 \\
\hline Root $\mathrm{C}$ & 17 & 32 & 44 & 33 & 23 & 13 & 23 \\
\hline \multicolumn{8}{|c|}{ Impact of forest cover change on $\mathrm{C}$ stocks $\left(\mathrm{Tg}^{-1}\right)^{\mathrm{d}}$} \\
\hline Conversion to cropland & 4.38 & 4.73 & 1.70 & 64.54 & 2.15 & - & 77.50 \\
\hline Conversion to agroforestry & 1.04 & 1.42 & 0.50 & 19.81 & 0.63 & - & 23.40 \\
\hline Impact of degradation & 0.29 & 2.46 & 0.39 & 26.11 & 0.42 & - & 29.68 \\
\hline Expected C losses from logging $(\mathrm{Tg})^{\mathrm{e}}$ & 44.35 & 64.96 & 72.57 & 98.73 & 30.54 & 0.56 & 311.71 \\
\hline
\end{tabular}

${ }^{a}$ Data on land area and forest management is obtained from Nasi et al. (2006)

${ }^{b}$ Data from deforestation and degradation rate were obtained from FAO (2006) and CBFP (2007).

${ }^{c}$ SOC was obtained from Henry (unpublished), aboveground C was obtained from FAO (2007) and root C was obtained from aboveground biomass using root/shoot ration for tropical humid region (Jackson et al., 1996)

${ }^{\mathrm{d}}$ Impact of deforestation and degradation was obtained using the $\%$ of $\mathrm{C}$ impacted by forest conversion

e Impact of logging was estimated using a coefficient of $10.2 \mathrm{Mg} \mathrm{C} \mathrm{ha}^{-1}$ obtained from Brown et al. (2005) and considering a time rotation of 40 years.

2004; van der Werf et al., 2004). Latest results published in this issue (Lehsten et al., 2009; Roberts et al., 2009) show lower values: $723 \pm 70$ and $855 \mathrm{Tg} \mathrm{C} \mathrm{y}^{-1}$, respectively, resulting into an average of $0.79 \mathrm{Pg} \mathrm{C}^{-1}$.

Wildfires are a prominent feature and intrinsic ecosystem component of savannas worldwide. Some theoretical models even attribute the existence of savannas, i.e. the cooccurrence of trees and grasses, to their high fire frequency (see Sankaran et al., 2004). The vast majority of African fire events occur in Savannas (Tansey et al., 2004). While the overall difference between "natural" and anthropogenicallydriven fire regime is difficult to be determined, it seems clear that currently the vast majority of fires are ignited by humans, mostly due to different land management practices (Saarnak, 2001). There are different theories about the relationship between fire frequency and standing biomass, but a better prevention of fires could lead to a much higher above and below ground biomass gain (Grace et al., 2006).

According to Lehsten et al. (2009) fires consume around $10 \%$ of Savanna NPP annually. Savanna systems subjected to a time-integrated relatively constant fire frequency have an almost neutral carbon balance, since the fire induced car- bon losses are offset by the consequent vegetation re-growth (Saarnak, 2001). However when merging the above C loss from savanna fires $\left(0.79 \mathrm{Pg} \mathrm{C} \mathrm{y}^{-1}\right)$ with the estimated NEP of savannas (excluding the fire component) the results show a residual carbon sink variable from 1.10 (using the field measurements) to $2.69 \mathrm{Pg} \mathrm{C} \mathrm{y}^{-1}$ (using the model estimates). Clearly, improved estimates and a more detailed analysis of all contributing processes are required to pin-point and reduce this variability and the major uncertainties.

\subsection{The role of deforestation (D) in the SSA carbon balance}

Approximately $16 \%$ of the world's forests are in Africa and around 4 million ha $\mathrm{yr}^{-1}$ of forest have been lost in the period 2000-2005 in Africa (FAO, 2006). In 2005, Africa had the highest rate of deforestation with $0.62 \%$ of annual loss of forest area. Most of the forest carbon losses were reported for the Central Africa, particularly in the Congo Basin countries. The Congo Basin forest is the world's second largest tropical forest, covering 223 million of hectares in six countries, and containing a quarter of the world's remaining tropical forest 
(FAO, 2006). Even if Africa showed the smallest deforested area of all tropical regions (Achard et al., 2004), an average size of 0.805 and 0.611 million hectares was deforested every year for the period 1900-2000 and 2000-2005 respectively (Table 4). Thus Africa has been contributing up to 35\% of total tropical land clearing from deforestation, with an annual carbon loss from deforestation of $0.37 \mathrm{Pg} \mathrm{C}^{-1}$ in the last decades (Houghton, 2003). Carbon losses through deforestation tend to be "permanent" in Africa, as afforestation and reforestation rates are modest, at less than $5 \%$ of annual deforestation.

Conversion from forest to cultivation through slash-andburn activities could decrease the aboveground $\mathrm{C}$ stock to $220 \mathrm{Mg} \mathrm{C} \mathrm{ha}^{-1}$ (the rate of recovery in fallow systems depending on biomass at the start of the fallow period) (KottoSame et al., 1997) and the belowground C stock to $24.4 \mathrm{Mg}$ $\mathrm{C} \mathrm{ha}^{-1}$ in humid and sub-humid tropics (Vagen et al., 2004).

On the basis of average $\mathrm{C}$ stocks in different Cameroon land uses (Fig. 3), which can be considered representative for SSA region, we have estimated that C losses from the conversion of forest to different croplands range from the highest value of $224 \mathrm{Mg} \mathrm{C} \mathrm{ha}^{-1}$ for crop mixtures (maize, groundnuts, cassava, banana) to the lowest value showed by cucumber based croplands $\left(59 \mathrm{Mg} \mathrm{C} \mathrm{ha}^{-1}\right)$. On the other hand, the conversion of forest to cocoa plantations led to $\mathrm{C}$ losses of about $133 \mathrm{Mg} \mathrm{C} \mathrm{ha}^{-1}$.

Based on these new values we can provide an approximate estimation of the SSA deforestation related emissions in Central Africa of $101 \mathrm{Tg} \mathrm{C} \mathrm{y}^{-1}$ (see Table 4). If we assume, for simplicity, similar rates of deforestation and land conversion for Eastern and South Africa forests the overall deforestation emission losses would be $251 \mathrm{Tg} \mathrm{C}^{-1}$. This estimate is lower than that by Houghton (2003), of $370 \mathrm{Tg} C$ $\mathrm{y}^{-1}$, which was based on the total forest area in Africa. If we correct for the total forest area of Africa (635 Mha), our estimate is $316 \mathrm{Tg} \mathrm{C}^{-1}$ which is comparable with the estimate of Houghton (2003) and thus we can keep $251 \mathrm{Tg}$ C $\mathrm{y}^{-1}$ as first approximation of the value of SSA emission by deforestation in our carbon balance calculation.

\subsection{The role of forest degradation (FD) in the SSA car- bon balance}

Deforestation and forest degradation are two different processes with different ecological consequences. Deforestation involves cutting, damaging and burning of forest and is mainly associated with slash and burn agriculture (FAO, 2006) in SSA, whereas forest degradation is mainly related to logging activities and forest encroachment by local population. While logging activities mostly correspond to clearcutting practices in Asia and America, in tropical Africa selective logging is practised. Degradation is less well documented than deforestation and is also more difficult to map. While deforestation due to cropland conversion can be reported by satellite imageries, forest degradation can not be easily accounted by remote sensing tools. Moreover, estimating the logging impact on $\mathrm{C}$ stocks it is difficult because of the missing information on illegal logging practices and the poorly documented amount of legal logging. However, when considering the impact of selective logging activities on C stocks, Brown et al. (2005) reported C losses of about $10 \mathrm{Mg} \mathrm{Cha}^{-1}$ of tropical forest in Congo, considering a time rotation of 40 years. By extrapolating this value using the area under forest management as reported in Table 4 for the Congo Basin and scaled to the overall SSA forest area, we obtain an annual emission rate for degradation equal to $82 \mathrm{Tg} \mathrm{C}^{-1}$.

To our knowledge, no data were available on the impact of degradation due to forest encroachment on $\mathrm{C}$ stocks. Therefore an alternative method to derive emission rates from encroachment was also used by assuming that $\mathrm{C}$ stocks in degraded forest were close to those measured in secondary forest (Fig. 3). From the difference between carbon stock of a natural forest and a degraded one it was estimated that the conversion from forest to degraded forest by encroachment led to $\mathrm{C}$ losses of about $98 \mathrm{Mg} \mathrm{Cha}^{-1}$.

After logging a natural regeneration of a secondary forest takes place and can revert carbon losses recovering carbon stocks at a certain point in time. Very few studies report the natural capacity of African ecosystems to regenerate after perturbations. Kotto-Same (1997) reported that about $74 \%$ of aboveground $\mathrm{C}$ was regenerated after a period of fallow of 18 years. According to the regression between time of fallow and $\mathrm{C}$ stocks, the total system $\mathrm{C}$ would be equal to the original natural forest after a period of 24 years (Kotto-Same, 1997).

\subsection{A first synthesis of the CarboAfrica results}

Table 5 summarises the first numbers derived from the CarboAfrica estimates together with bibliographic data and compares them with the UNFCCC national reporting estimates. By this preliminary synthesis, the provisional biogenic carbon balance of SSA varies from around a smaller value of $0.16 \mathrm{Pg} \mathrm{C} \mathrm{y}^{-1}$ (using UNFCCC estimates, that do not consider explicitly the net ecosystem productivity of savannas) to $1.00 \mathrm{Pg} \mathrm{C} \mathrm{y}^{-1}$. Other studies, such as Williams et al. (2007) and Ciais et al. (2009), showed a neutral balance or a small sink of $0.15 \mathrm{Pg} \mathrm{C}^{-1}$, respectively. This last value is very similar to the one derived from UNFCCC estimates. The inclusion of the fossil fuel emissions to derive the overall SSA carbon balance, reduces the natural sink potential to $0.81 \mathrm{Pg} \mathrm{C} \mathrm{y}^{-1}$, and can even turn it into a small source of $0.03 \mathrm{Pg} \mathrm{C} \mathrm{y}^{-1}$ if we consider the UNFCCC estimates (Table 5). Model estimates for forest and savanna NEP would lead to a larger unrealistic biogenic sink of 3.23 $\mathrm{Pg} \mathrm{C}^{-1}$.

Therefore the terrestrial ecosystem component of SSA seems to be a carbon sink, but there is still a high uncertainty especially about the savanna role (depending on the used data: in situ, national communications, models), that leads 
Table 5. Comparison between preliminary carbon balance estimates for SSA derived from CarboAfrica data (supplemented by bibliographic data, as specified below) and the UNFCCC national communication data. NEP(F) = Net Ecosystem Productivity of Forests; NEP(S) $=$ Net Ecosystem Productivity of Savannas; $\mathrm{D}=$ emissions from Deforestation; FD = emissions from Forest Degradation; EFS = Emissions from Savanna Fires; A = emissions from Agriculture; FF = emissions from Fossil Fuel. Biogenic $=N E P(F)+N E P(S)+D+F D+E F S+A . ~ D a t a$ are given in $\mathrm{Pg} \mathrm{C}^{-1}$. NEP(F) is taken from Lewis et al. (2009); NEP(S) is derived from CarboAfrica and bibliographic data listed in Table 3; FF is taken from Canadell et al. (2009).

\begin{tabular}{|c|c|c|c|c|c|c|c|c|c|}
\hline & \multicolumn{2}{|c|}{ Sinks } & \multicolumn{4}{|c|}{ Sources } & \multicolumn{3}{|c|}{ SSA C-balance } \\
\hline & $\mathrm{NEP}(\mathrm{F})$ & $\mathrm{NEP}(\mathrm{S})$ & D & FD & EFS & A & FF & Biogenic & Total \\
\hline & 0.34 & 1.89 & -0.25 & -0.08 & -0.79 & -0.11 & -0.18 & 1.00 & 0.81 \\
\hline UNFCCC & $\begin{array}{r}\text { Rem } \\
0\end{array}$ & $\begin{array}{l}\text { vals } \\
8\end{array}$ & & $\begin{array}{r}\text { LUCF } \\
-\end{array}$ & $\begin{array}{l}\text { hissions } \\
40\end{array}$ & $\begin{array}{c}\text { A } \\
-0.11\end{array}$ & -0.19 & 0.16 & -0.03 \\
\hline
\end{tabular}

in turn to a high uncertainty about this sink value. The few available annual NEP values from in situ estimates highly differ each other, and the average model result also hides a large variability among the different model outputs, ranging from 1.3 to $3.9 \mathrm{Pg} \mathrm{C} \mathrm{y}^{-1}$. Moreover, terrestrial ecosystem models have not been used in depth for savanna ecosystems up to now, and it is likely that a number of crucial processes are not yet well represented. This highlights a crucial research need as the importance of African savannas for dynamics of the African carbon balance is also seen in their large interannual variability, that seems to be strongly related to water balance. In addition, from preliminary CarboAfrica results (Castaldi, De Grandcourt and collaborators, unpublished) it seems that African savannas might represent a significant source of $\mathrm{CH}_{4}$ by termite activity, thus reducing their sink potential. Further studies are therefore needed to better quantify the $\mathrm{CH}_{4}$ source value and the role of land characteristics and disturbance on this source. Hence, increasing the field efforts and improving the terrestrial modelling capacity for these regions shall be a key focus in future African carbon-cycle research, in particular in the frame of the CarboAfrica project, that is producing new carbon flux data to refine and improve the above estimates.

\section{Conclusions}

The preliminary results of the CarboAfrica project suggested that the biogenic SSA carbon balance is a delicate equilibrium between a number of large fluxes, that are both human and climate related, resulting in a probable carbon sink value. There is still a high uncertainty about this sink value, due to 1) the current data used which are preliminary and need validation; 2) the generalization of the Africa's land surface considered as savanna, that leads to a consequent overestimation of the total savanna NEP, 3) the lack of process representation in terrestrial models, and 4) the lack of an optimal coverage of the most representative ecosystem types (in particular tropical forests). Nevertheless, this first analysis shows that
Africa could have a probable potential for carbon sequestration larger than expected, which should not be ignored for studies of global carbon cycle-climate interactions.

Savannas play a dominant role in shaping the SSA carbon balance, due to their large land cover extension, their fire regime, and the strong interannual variability of their plant productivity.

Forests seems to play an important role as carbon sink, and this is confirmed also by the recent study of Lewis et al. (2009), showing that in the last 40 years there was an increase of $0.34 \mathrm{Pg} \mathrm{C} \mathrm{y}^{-1}$ in the carbon storage in African tropical forests.

Even if fossil fuel emissions from SSA are quite low, they are dramatically increasing and they already play a key role by reducing the natural sink potential. In effect they could turn the SSA carbon balance from a sink to a source value.

By these results, a critical and urgent need for better understanding the main components of the African carbon balance has emerged, in particular for better addressing the role of savannas and tropical forests. Moreover, further studies on disturbances and plant and soil processes, including methane and nitrogen fluxes, should be considered to better understand the role of $\mathrm{CO}_{2}$ and other non $\mathrm{CO}_{2}$ greenhouse gases in the overall SSA GHGs budget. This interest is growing from the fact that agriculture is rapidly expanding also in response to biofuels demand. This rapid change in the SSA landscape and the increase in fossil fuel emissions have also to be considered in future projection of the carbon cycle of the region.

CarboAfrica project, with its observational network, will indeed provide a unique and increased dataset of field measurements for improving model parameterization and validate African regional estimates. The next researches in the frame of the CarboAfrica project will try to reduce the uncertainties in order to clarify the Sub-Saharan African role in the global carbon cycle. 


\begin{tabular}{ll}
\hline TAr & Tropical rainforest \\
TAwa & Tropical moist deciduous forest \\
TAwb & Tropical dry forest \\
TBSh & Tropical shrubland \\
TBWh & Tropical desert \\
TM & Tropical mountain system \\
SCf & Subtropical humid forest \\
SCs & Subtropical dry forest \\
SBSh & Subtropical steppe \\
\hline SBWh & Subtropical desert \\
SM & Subtropical mountain system \\
TeDo & Temperate oceanic forest \\
TeDc & Temperate continental forest \\
TeBSk & Temperate steppe \\
TeBWk & Temperate desert \\
TeM & Temperate mountain system \\
Ba & Boreal coniferous forest \\
Bb & Boreal tundra woodland \\
BM & Boreal mountain system \\
P & Polar \\
Water & Water \\
n.d. & No data \\
\hline & \\
\hline
\end{tabular}

Fig. A1. Legend of the classes of the Ecological Zones shown in Fig. 1.

Acknowledgements. Financial support for this scientific research came from the European Commission, which has been funding the project "CarboAfrica" (GOCE, 037132) under the 6 Framework Programme (FP6). The authors thank Gloria D. Djagbletey of FORIG and Ms Marion Chesnes, for their contribution during the field work at Bobiri Forest Reserve (Ghana), and Antonio Martucci (FAO) for his graphical support. Thanks to all the CarboAfrica partners and collaborators, which have made possible this project.

Edited by: S. Bouillon

\section{References}

Achard, F., Eva, H. D., Mayaux, P., Stibig, H.-J., and Belward, A.: Improved estimates of net carbon emissions from land cover change in the tropics for the 1990s. Global Biogeochem. Cycles, 18, GB2008, doi:10.1029/2003GB002142, 2004.

Andreae, M. O.: Biomass burning: its history, use and distribution and its impact on the environmental quality and global climate, Global Biomass Burning: Atmospheric, Climatic and Biospheric Implications, Levine J. S., MIT Press, Cambridge, Massachusetts, USA, 1991.

Andreae, M. O.: The influence of tropical biomass burning on climate and the atmospheric environment, edited by: Oremland, R. S., Biogeochemistry of Global Change: Radiatively Active Trace Gases, 113-150, New York, Chapman and Hall, 1993.

Archibald, S. A., Kirton, A., van der Merwe, M. R., Scholes, R. J., Williams, C. A., and Hanan, N.: Drivers of inter-annual variabil- ity in Net Ecosystem Exchange in a semi-arid savanna ecosystem, South Africa, Biogeosciences, 6, 251-266, 2009, http://www.biogeosciences.net/6/251/2009/.

Baker, D. F., Law, R. M., Gurney, K. R., Rayner, P., Peylin, P., Denning, A. S., Bousquet, P., Bruhwiler, L., Chen, Y. H., Ciais, P., Fung, I. Y., Heimann, M., John, J., Maki, T., Maksyutov, S., Masarie, K., Prather, M., Pak, B., Taguchi, S., and Zhu, Z:: TransCom 3 inversion inter comparison: impact of transport model errors on the interannual variability of regional $\mathrm{CO}_{2}$ fluxes, 1988-2003. Global Biogeochem. Cycles, 20, GB1002, doi:10.1029/2004GB002439, 2006.

Brown, S., Pearson, T., Moore, N., Parveen, A., Ambagis, S., and Shoch, D.: Impact of selective logging on the carbon stocks of tropical forests: Republic of Congo as a case study, Winrock International, available at http://carpe.umd.edu/resources/ Documents/rpt carbon congo 32005 winrock.pdf/view, 2005.

Brown, S.: Estimating biomass and biomass change of tropical forests: a primer, FAO Forestry Paper 134, FAO, Rome, 1997.

Brümmer, C., Falk, U., Papen, H., Szarzynski, J., Wassmann, R., and Brüggemann, N.: Diurnal, seasonal, and interannual variation in carbon dioxide and energy exchange in shrub savanna in Burkina Faso (West Africa), J. Geophys. Res., 113, G02030, doi:10.1029/2007JG000583, 2008.

Canadell, J. G., Raupach, M. R., and Houghton, R. A.: Anthropogenic $\mathrm{CO}_{2}$ emissions in Africa, Biogeosciences, 6, 463-468, 2009, http://www.biogeosciences.net/6/463/2009/.

Cao, M. K., Zhang, Q. F., and Shugart, H. H.: Dynamic responses of African ecosystem carbon cycling to climate change, Climate Res., 17, 183-193, 2001.

CBFP (Congo Basin Forest Partnership): The forests of the Congo Basin, State of the Forest 2006, edited by: Devers, D. and vande Weghe, J. P., available at http://www.cbfp.org/keydocs.html?file=docs/key_docs/State\% 20of\%20the\%20Forest\%202006\%20small.pdf, 2007.

Chevallier, F., Fortems, A., Bousquet, P., Pison, I., Szopa, S., Devaux, M., and Hauglustaine, D. A.: African CO emissions between years 2000 and 2006 as estimated from MOPITT observations, Biogeosciences, 6, 103-111, 2009, http://www.biogeosciences.net/6/103/2009/.

Chidumayo, E. N.: Changes in miombo woodland structure under different land tenure and use systems in central Zambia, J. Biogeogr., 29, 1619-1626, 2002.

Ciais, P., Piao, S.-L., Cadule, P., Friedlingstein, P., and Chédin, A.: Variability and recent trends in the African terrestrial carbon balance, Biogeosciences, 6, 1935-1948, 2009, http://www.biogeosciences.net/6/1935/2009/.

FAO: Global Forest Resources Assessment 2005, Progress towards sustainable forest management, FAO Forestry paper 147, Food and Agriculture Organization of the United Nations, Rome, 2006.

FAO: State of the World's Forests 2007, The Food and Agriculture Organization of the United Nations, Rome, 144 pp., 2007.

Friedlingstein, P., Cadule, P., Piao, S. L., Ciais, P., and Sitch, S.: The African contribution to the global climate-carbon cycle feedback of the 21st century, Biogeosciences Discuss., 5, 4847-4866, 2008, http://www.biogeosciences-discuss.net/5/4847/2008/.

Grace, J., San José, J., Meir1, P., Miranda, H. S., and Montes, R. A.: Productivity and carbon fluxes of tropical savannas, J. Biogeogr., 33, 387-400, 2006. 
Hanan, N. P., Kabat, P., Dolman, A. J., and Elbers J. A.: Photosynthesis and carbon balance of a Sahelian fallow savanna, Global Change Biol., 4, 523-538, 1998.

Hao, W. M., Ward, D. E., Olbu, G., and Baker, S. P.: emissions of $\mathrm{CO}_{2}$, Co and hydrocarbons from fires in diverse African savanna ecosystems, J. Geophys. Res., 101, 23577-23584, 1996.

Houghton, R. A. and Hackler, J. L.: Emissions of carbon from land use change in sub-Saharan Africa, J. Geophys. Res., 111, G02003, doi:10.1029/2005JG000076, 2006.

Houghton, R. A.: The annual net flux of carbon to the atmosphere from changes in land use 1850-1990, Tellus B, 51, 298-313, doi:10.1034/j.1600-0889.1999.00013.x, 1999.

Houghton, R. A.: Revised estimates of the annual net flux of carbon to the atmosphere from changes in land use and land management 1850-2000, Tellus B, 55, 378-390, 2003.

IPCC: Climate Change 2007: Synthesis Report, Contribution of Working Groups I, II and III to the Fourth Assessment Report of the Intergovernmental Panel on Climate Change, Core writing Team, edited by: Pachauri, R. K. and Reisinger, A., IPCC, Geneva, Switzerland, 104 pp., 2007a.

IPCC: Changes in Atmospheric Constituents and Radiative Forcing, edited by: Solomon, S., Qin, D., Manning, M., Chen, Z., Marquis, M., Averyt, K. B., Tignor, M., and Miller, H. L., Climate Change 2007: The Physical Science Basis. Contribution of Working Group I to the Fourth Assessment, Cambridge University Press, Cambridge, United Kingdom and New York, NY, USA, 129-234, 2007b.

Ito, A. and Penner, J. E.: Global estimates of biomass burning emissions based on satellite imagery for the year 2000, J. Geophys. Res., 109, D14505, doi:10.1029/2003JD004423, 2004.

Jackson, R. B., Canadell, J., Ehleringer, J. R., Mooney, H. A., Sala, O. E., and Schulze, E. D.: A global analysis of root distributions for terrestrial biomes, Oecologia, 108, 389-411, 1996.

Kanmegne, J.: Slash and Burn Agriculture in the Humid Forest Zone of Southern Cameroon: Soil Quality Dynamics, Improved Fallow Management and Farmers' Perceptions, Wageningen University, Wageningen 180 pp., 2004.

Kituyi, E., Wandiga, S. O., Andreae, M. O., and Helas, G.: Biomass burning in Africa: role in atmospheric change and opportunities for emission mitigation, edited by: Sum Low, P., Climate Change and Africa, Cambridge University Press, Cambridge, 79-89, 2005.

Kotto-Same, J., Woomer, P. L., Appolinaire, M., and Louis, Z.: Carbon dynamics in slash-and-burn agriculture and land use alternatives of the humid forest zone in Cameroon, Agriculture, Ecosystems and Environment, 65, 245-256, 1997.

Kutsch, W. L., Hanan, N., Scholes, B., McHugh, I., Kubheka, W., Eckhardt, H., and Williams, C.: Response of carbon fluxes to water relations in a savanna ecosystem in South Africa, Biogeosciences, 5, 1797-1808, 2008, http://www.biogeosciences.net/5/1797/2008/.

Lehsten, V., Tansey, K., Balzter, H., Thonicke, K., Spessa, A., Weber, U., Smith, B., and Arneth, A.: Estimating carbon emissions from African wildfires, Biogeosciences, 6, 349-360, 2009, http://www.biogeosciences.net/6/349/2009/.

Lewis, S. L., Lopez-Gonzalez, G., Sonké, B., Affum-Baffoe, K., Baker, T. R., Ojo, L. O., Phillips, O. L., Reitsma, J. M., White, L., Comiskey, J. A., Djuikouo K., M.-N., Ewango, C. E. N., Feldpausch, T. R., Hamilton, A. C., Gloor, M., Hart, T.,
Hladik, A., Lloyd, J., Lovett, J. C., Makana, J.-R., Malhi, Y., Mbago, F. M., Ndangalasi, H. J., Peacock, J., Peh, K. S.-H., Sheil, D., Sunderland, T., Swaine, M. D., Taplin, J., Taylor, D., Thomas, S. C., Votere, R., and Wöll, H.: Increasing carbon storage in intact African tropical forests, Nature, 457, 1003-1007, doi:10.1038/nature07771, 2009.

Merbold, L., Ardö, J., Arneth, A., Scholes, R. J., Nouvellon, Y., de Grandcourt, A., Archibald, S., Bonnefond, J. M., Boulain, N., Brueggemann, N., Bruemmer, C., Cappelaere, B., Ceschia, E., El-Khidir, H. A. M., El-Tahir, B. A., Falk, U., Lloyd, J., Kergoat, L., Le Dantec, V., Mougin, E., Muchinda, M., Mukelabai, M. M., Ramier, D., Roupsard, O., Timouk, F., Veenendaal, E. M., and Kutsch, W. L.: Precipitation as driver of carbon fluxes in 11 African ecosystems, Biogeosciences, 6, 1027-1041, 2009, http://www.biogeosciences.net/6/1027/2009/.

Mosier, A. R.: Gas flux measurements techniques with special reference to techniques suitable for measurements over large ecological uniform areas, Soils and the greenhouse effect, edited by: Bouwman, A. F., John Wiley and Sons Ltd. Chichester, 289-301, 1990.

Nasi, R., Cassagne, B., and Billand, A.: Forest management in Central Africa: where are we?, Int. For. Rev., 8, 14-20, 2006.

Palm, C. A., Woomer, P. L., Alegre, J., Arevalo, L., Castilla, C., Cordeiro, D. G., Feigl, B., Hairiah, K., Kotto-Same, J., Mendes, A., Moukam, A., Murdiyarso, D., Njomgang, R., Parton, W. J., Ricse, A., Rodrigues, V., Sitompul, S. M., and van Noordwijk, M.: Carbon sequestration and trace gas emissions in slash-andburn and alternative land-uses in the humid tropics, Alternative to Slash-and-Burn Climate ChangeWorking Group Final Report Phase II, ICRAF, Nairobi, Kenya, 36 pp, 1999.

Roberts, G., Wooster, M. J., and Lagoudakis, E.: Annual and diurnal african biomass burning temporal dynamics, Biogeosciences, 6, 849-866, 2009, http://www.biogeosciences.net/6/849/2009/.

Rödenbeck, C., Houweling, S., Gloor, M., and Heimann, M.: Timedependent atmospheric $\mathrm{CO}_{2}$ inversions based on interannually varying tracer transport, Tellus B, 55, 488-497, 2003.

Saarnak, C. F.: A shift from natural to human-driven fire regime: implications for trace-gas emissions, Holocene, 11, 373-375, 2001.

Sankaran, M., Ratnam, J., and Hanan, N. P.: Tree-grass coexistence in savannas revisited - insights from an examination of assumptions and mechanisms invoked in existing models, Ecol. Lett., 7, 480-490, 2004.

Scholes, R. J. and Walker, B. H. (Eds.): An African savanna: synthesis of the Nylsvley study, Cambridge University Press, Cambridge, UK, 1993.

Scholes, R. J. and Hall, D. O.: The Carbon Budget of Tropical Savannas, Woodlands and Grasslands, edited by: Breymeyer, A. I., Hall, D. O., Melillo, J. M., and Ågren, G. I., Global Change: Effects on Coniferous Forests and Grasslands, SCOPE 56, John Wiley \& Sons, Chichester, 69-100, 1996.

Seaquist, J. W., Hickler, T., Eklundh, L., Ardö, J., and Heumann, B. W.: Disentangling the effects of climate and people on Sahel vegetation dynamics, Biogeosciences, 6, 469-477, 2009, http://www.biogeosciences.net/6/469/2009/.

Sjöström, M., Ardö, J., Eklundh, L., El-Tahir, B. A., El-Khidir, H. A. M., Hellström, M., Pilesjö, P., and Seaquist, J.: Evaluation of satellite based indices for gross primary production estimates 
in a sparse savanna in the Sudan, Biogeosciences, 6, 129-138, 2009, http://www.biogeosciences.net/6/129/2009/.

Smith, B., Prentice, I. C., and Sykes, M. T.: Representation of vegetation dynamics in the modelling of terrestrial ecosystems: comparing two contrasting approaches within European climate space, Global Ecol. Biogeogr., 10, 621-637, 2001.

Smith, K. A., Clayton, H., McTaggart, I. P., Thomson, P. E., Arah, J. R. M., and Scott, A.: The measurement of nitrous oxide emissions from soil by using chambers, Philosophical Transactions: Phys. Sci. Eng., Lond, 351, 327-338, 1995.

Tansey, K., Grégoire, J.-M., Stroppiana, D., Sousa, A., Silva, J. M. N., Pereira, J. M. C., Boschetti, L., Maggi, M., Brivio, P. A., Fraser, R., Flasse, S., Ershov, D., Binaghi, E., Graetz, D., and Peduzzi, P.: Vegetation burning in the year 2000: Global burned area estimates from SPOT VEGETATION data, J. Geophys. Res., 109, D14S03, doi:10.1029/2003JD003598, 2004.

Tan, Z., Tieszen, L. L., Tachie-Obeng, E., Liu, S., and Dieye, A. M.: Historical and simulated ecosystem carbon dynamics in Ghana: land use, management, and climate, Biogeosciences, 6, 45-58, 2009, http://www.biogeosciences.net/6/45/2009/.

Thonicke, K., Spessa, A., Prentice, I. C., Harrison, S. P., and Carmona-Moreno, C.: The influence of vegetation, fire spread and fire behaviour on global biomass burning and trace gas emissions, Global Change Biol., submitted, 2009.

United Nations, World Population Prospects: The 2006 Revision, Population Division of the Department of Economic and Social Affairs of the United Nations Secretariat, available at: http://esa. un.org/unpp, 2006.
Vagen, T. G., Lal, R., and Singh, B. R.: Soil carbon sequestration in sub-saharan Africa: a review, Land Degraded Develop., 16, 54-71, 2004.

van der Werf, G. R., Randerson, J. T., Collatz, G. J., Giglio, L., Kasibhatla, P. S., Arellano, A. F., Olsen, S. C., and Kasischke, E. S.: Continental-scale partitioning of fire emissions during the 1997 to 2001 El Niño/La Niña period, Science, 303, 73-76, 2004.

van der Werf, G. R., Randerson, J. T., Giglio, L., Collatz, G. J., Kasibhatla, P. S., and Arellano Jr., A. F.: Interannual variability in global biomass burning emissions from 1997 to 2004, Atmos. Chem. Phys., 6, 3423-3441, 2006, http://www.atmos-chem-phys.net/6/3423/2006/.

Veenendaal, E. M., Kolle, O., and Lloyd, J.: Seasonal variation in energy fluxes and carbon dioxide exchange for a broadleaved semi-arid savanna (Mopane woodland) in southern Africa, Global Change Biol., 10, 318-328, 2004.

Weber, U., Jung, M., Reichstein, M., Beer, C., Braakhekke, M. C., Lehsten, V., Ghent, D., Kaduk, J., Viovy, N., Ciais, P., Gobron, N., and Rödenbeck, C.: The interannual variability of Africa's ecosystem productivity: a multi-model analysis, Biogeosciences, 6, 285-295, 2009, http://www.biogeosciences.net/6/285/2009/.

Williams, C. A., Hanan, N. P., Neff, J. C., Scholes, R. J., Berry, J. A., Denning, A. S., and Baker, D. F.: Africa and the global carbon cycle, Carb. Bal. Manag., 2, 3, doi:10.1186/1750-06802-3, 2007. 